\title{
Optimization of Extrusion Conditions for Production of Instant Millet-Soybean Blended Flour
}

\author{
Natukunda Sheila \\ School of Food Technology, Nutrition and Bioengineering, Makerere University, \\ Kampala, Uganda \\ Kamoga Kenneth Ryan \\ School of Food Technology, Nutrition and Bioengineering, Makerere University, \\ Kampala, Uganda \\ Kizza Mawanda David \\ School of Food Technology, Nutrition and Bioengineering, Makerere University, \\ Kampala, Uganda
}

Faith M. Namayengo

Department of Human Nutrition and Home Economics, Kyambogo University, Uganda

Muyonga John Herbert (Correspondence)

School of Food Technology, Nutrition and Bioengineering, Makerere University, Kampala, Uganda

Received: May 24, 2020 Accepted: July 10, 2020 Published: July 16, 2020

doi:10.5296/jfs.v9i1.17358 URL: https://doi.org/10.5296/jfs.v9i1.17358

\begin{abstract}
This study developed an optimized protocol for production of instant millet-soybean flour with high solubility. Response surface methodology was used to determine optimal processing conditions for desired water absorption index (WAI) and water solubility index (WSI). Three levels of extrusion temperature $\left(130,150\right.$ and $\left.180{ }^{\circ} \mathrm{C}\right)$ and feed moisture $(15$, 20 and $25 \%$ ) were used. Nutritional composition, consumer acceptability and shelf stability
\end{abstract}




\section{MInstitute ${ }^{\text {Macrothink }}$}

of millet-soybean blend produced using optimal extrusion conditions were determined. Analysis of variance showed that the contribution of a quadratic model was significant for WAI and WSI, with high correlation coefficients $\left(\mathrm{R}^{2}=0.80\right.$ and 0.75 , respectively). Response surface plots showed that increase in temperature significantly increased both WAI and WSI, while increase in feed moisture significantly increased WAI and decreased WSI. The optimal extrusion conditions were found to be: barrel temperature $159{ }^{\circ} \mathrm{C}$ and feed moisture of $25 \%$ with product predicted WAI of $2.124 \mathrm{~g} \mathrm{H}_{2} \mathrm{O} / \mathrm{g}$ and WSI of $51.30 \%$. Experimental values for responses of products made using optimized conditions were in agreement with the predicted values. Gruels made using the extruded millet-soybean flour were acceptable but with lower consumer acceptability $(\mathrm{p}<0.05)$ scores than the commercially available and extruded millet only flour. Yeasts and molds as well as coliforms were not detected. Total plate count results ranged from 1.35 to $2.9 \mathrm{log} \mathrm{cfu} / \mathrm{g}$ within one month of storage. This study provides information on the conditions that are suitable for processing an acceptable highly soluble instant millet-soybean flour.

Keywords: Optimization, Extrusion cooking, Blended flours, Response surface methodology, Complementary flours

\section{Introduction}

Finger millet (Eleucine coracana), like other cereals is a high starch food but is superior to major cereals like maize, wheat and rice in terms of protein content and amino acid profile, iron and vitamins content (Barbeau \& Hilu, 1993). However, finger millet also contains the anti-nutrients phytic acid (Ali et al., 2009), phenolic compounds (Dykes \& Rooney, 2006), oxalates, protease inhibitors and goitrogens (Mbithi-Mwikya et al., 2002). These anti-nutritional components chelate minerals in the gastro intestinal tract, reducing their bioavailability (Elmaki et al., 2007). Similar to other cereals,finger millet has an inherent problem of low nutrient density (high bulk) (Mbithi-Mwikya et al., 2002). Additionally, finger millet is low in some essential amino acids, notably lysine and tryptophan. Combining of finger millet with legumes leads to protein quality complementation (Navam et al., 2014).

Soybean (Glycine max) is rich in quality protein (high in lysine) and has potential to complement finger millet (Boonyasirikool \& Charunuch, 2000). Soybeans contain 40\% proteins, $23 \%$ carbohydrates, $20 \%$ oils with reasonable amount of minerals and vitamins. Soybean is a relatively inexpensive source of quality proteins (Balasubramanian et al., 2012). The blend of soybean and finger millet can yield a product high in energy and in proteins. However, presence of anti-nutrients in both soybean and finger millet reduce their protein and mineral bioavailability.

Heat treatment, including extrusion, leads to improved nutrient density of porridges (Diaz et al., 2013) and reduction in antinutrients (Sundarrajan, 2014; Alonso et al., 2001), resulting in protein and mineral bioavailability improvement (Anton et al., 2009; Vargas-Solorzano et al., 2014). Extrusion cooking is a high temperature-short time, processing technique that has been employed to produce a variety of high quality food products (Semasaka et al., 2010; Seth \& Rajamanickam, 2012). Extruders have low operating cost and exhibit higher throughput compared to other cooking methods. They combine energy efficiency and versatility (Huber, 2001). Extruded blends of cereals and legumes have higher protein content and the proteins exhibit higher protein efficiency ratio than raw mixtures (Semasaka et al., 2010). Poor 
solubility in extruded flours leads to consumer acceptability problems. The purpose of this study was to develop an optimized protocol for production of highly soluble instant millet-soybean flour. To the best of our knowledge, there is no previous report in literature of the optimal conditions for extrusion of millet-soybean blend for use in porridges.

\section{Materials and Methods}

\subsection{Materials}

\subsubsection{Finger Millet and Soybean Flours}

Clean millet and soybeans grains were procured from wholesalers in Nakasero market (Kampala, Uganda). Soybean grains were roasted for 15 minutes in an open sauce pan using a gas flame prior to milling. The soybean grains were stirred approximately every 3 minutes during roasting. Millet and roasted soybean grains were separately milled using 30B-C mill (Changzhou Erbang Drying Equipment Co. Ltd, Changzhou, China) to pass through a 250 $\mu \mathrm{m}$ sieve, blended (70:30 millet: soy flour) and the flour used for extrusion.

\subsection{Optimization of Conditions for Extrusion of Millet-Soybean Composite Flour}

The millet-soybean flour blend was conditioned to varied moisture content of $15-25 \%$ according to experimental design (Table 1) and mixed in a motor mixer (Roncheng city, China) for 15 minutes and then extruded in a double screw co-rotating extruder feed machine DP-70-111 (Jinan Eagle Food Machinery Co. Ltd., Jinan City-Shadong Province China). Extrusion was done at feeding frequency of $30 \mathrm{~Hz}$, cutting frequency of $50 \mathrm{~Hz}$ and feed temperature of $60^{\circ} \mathrm{C}$.

Table 1. Processing variables for extruded instant millet-soy flour used in the D-optimal design

\begin{tabular}{|c|c|c|c|c|c|}
\hline \multirow[t]{2}{*}{ Variable } & \multirow[t]{2}{*}{ Symbol } & \multirow[t]{2}{*}{ Units } & \multicolumn{3}{|c|}{ Coded and actual variables } \\
\hline & & & -1 & 0 & +1 \\
\hline $\begin{array}{l}\text { Barrel } \\
\text { temperature }\end{array}$ & $\mathrm{X}_{1}$ & ${ }^{\circ} \mathrm{C}$ & 130 & 150 & 180 \\
\hline $\begin{array}{l}\text { Feed } \\
\text { moisture } \\
\text { content }\end{array}$ & $\mathrm{X}_{2}$ & $\%$ & 15 & 20 & 25 \\
\hline
\end{tabular}

Three internal barrel temperature $\left(130,150\right.$ and $180^{\circ} \mathrm{C}$ ) levels were used (Table 2), while popping temperature was set at $130{ }^{\circ} \mathrm{C}$. The diameter of the die used was $4 \mathrm{~mm}$. After extrusion the extrudate was dried at $90{ }^{\circ} \mathrm{C}$ for 15 minutes using an oven (DP-DKX-11, Jinan Eagle Machine Co. Ltd). The dry extrudate was milled using a 30 B-C mill (Changzhou Erbang Drying Equipment Co. Ltd., China), sealed in polythene bags and stored at $4{ }^{\circ} \mathrm{C}$ until analysis was done. 
Table 2. D-Optimal design used to optimize levels of barrel temperature and moisture for high soluble composite flour

\begin{tabular}{llllll}
\hline \multicolumn{2}{c}{ Coded experimental plan } & & & \multicolumn{2}{l}{ Real experimental plan } \\
Standard order & $\begin{array}{l}\text { Run } \\
\text { order }\end{array}$ & $\begin{array}{l}\text { Temperature } \\
\left({ }^{\circ} \mathrm{C}\right)\end{array}$ & $\begin{array}{l}\text { Feed } \\
\text { Moisture } \\
(\%)\end{array}$ & $\begin{array}{l}\text { Temperature } \\
\left({ }^{\circ} \mathrm{C}\right)\end{array}$ & $\begin{array}{l}\text { Moisture } \\
(\%)\end{array}$ \\
\hline 15 & 1 & -1 & +1 & 130 & 25 \\
13 & 2 & +1 & +1 & 180 & 25 \\
1 & 3 & +1 & -1 & 180 & 15 \\
8 & 4 & +1 & -1 & 180 & 15 \\
9 & 5 & -1 & 0 & 130 & 20 \\
14 & 6 & +1 & -1 & 180 & 15 \\
2 & 7 & -1 & 0 & 130 & 20 \\
11 & 8 & 0 & -1 & 150 & 15 \\
4 & 9 & -1 & -1 & 130 & 20 \\
12 & 10 & 0 & 0 & 150 & 15 \\
3 & 11 & 0 & -1 & 150 & 15 \\
10 & 12 & 0 & -1 & 150 & 25 \\
5 & 13 & +1 & +1 & 180 & 15 \\
7 & 14 & 0 & -1 & 150 & 150 \\
6 & 15 & 0 & 0 & & 20 \\
\hline
\end{tabular}

\subsubsection{Experimental Design for Optimization of Protocol for Production of Instant Millet- Soybean Composite Flour}

The optimum conditions for extrusion of the millet-soybean blend were determined using response surface methodology (Myers et al., 2009). Design Expert (Version 7.0.0, Stat-Ease 4Inc., Minneapolis, MN) was employed for experimental design, data analysis and model construction. The D-optimal response surface design with a quadratic model was employed to determine the effects of two independent variables: barrel temperature $\left(X_{1},{ }^{\circ} \mathrm{C}\right)$ and moisture $\left(X_{2}, \%\right)$ on the responses which included; water absorption index (WAI) and water solubility index (WSI).

A two-factor and a three level D-optimal design consisting of 12 independent experimental runs, including 2 replicates at the centre point, were employed for both barrel temperature and feed moisture content. The experimental design of the coded and actual levels of variables is shown in Table 1 and Table 2. The relationship between input and response variables was established (Eq. 1), which includes linear, quadratic and interaction terms. The response functions (y) were the dependent variables (water absorption index and 


\section{Macrothink}

water-soluble index) which were related to independent variables coded $\mathrm{x}_{\mathrm{i}}$ and $\mathrm{x}_{\mathrm{j}}$ for temperature and water content in Equation 1 and 2 respectively. The second-degree polynomial model proposed for response (y) to the processing condition is henceforth showed.

$$
\hat{y}=\hat{3}_{0}+\sum_{i=1}^{h} \hat{3}_{i} x_{i}+\sum_{i=1}^{k} \hat{3}_{j ;} \mathrm{r}_{i}^{2}+\sum_{i=1}^{k} \sum_{j=1}^{j-1} \hat{3}_{j} x_{j} x_{j}
$$

\section{Simplified as equation 2}

$$
\mathrm{Y}=\mathrm{B}_{0}+\mathrm{B}_{1 \mathrm{X}_{1}}+\mathrm{B}_{2 \mathrm{X}_{2}}+\mathrm{B}_{12} \mathrm{X}_{1} \mathrm{X}_{2}+\mathrm{B}_{11} \mathrm{X}_{11}+\mathrm{B}_{22} \mathrm{X}_{22}
$$

The Regression coefficients of the polynomial equation were represented by $\mathrm{B}_{0}$, a constant term that fixes the response at the central point of the experiment, $\mathrm{B}_{1}$ and $\mathrm{B}_{2}$ (linear effects), $\mathrm{B}_{11}$ and $\mathrm{B}_{22}$ (quadratic effects) and $\mathrm{B}_{12}$ (interaction effects between variable 1 and 2) (Myers et al., 2009).

A D-Optimal design (Table 2) was used to determine optimum feed moisture content and internal barrel temperature for millet-soybean flour extrusion, with the aim of maximizing WSI and minimizing WAI.

\subsubsection{Optimization}

Numerical optimization technique using the desirability function approach (Derringer \& Suich, 1980) was employed to establish the optimum level of processing extrusion barrel temperature $\left(x_{1}\right)$ and feed moisture content $\left(\mathrm{x}_{2}\right)$ for composite flour. Optimized proportions of the independent variables ( $x_{1}$ and $x_{2}$ ) were further applied to validate the model. All statistical analyses were performed using Design - Expert software (v.7.0.0, Stat Ease Inc., Minneapolis, Minnesota, USA.

\subsection{Analyses}

\subsubsection{Water Absorption and Solubility Index}

Determination of WAI and WSI entailed solubilization and gravimetric separation (Bryant et al., 2001; Semasaka et al., 2010). Briefly, one gram of sample was suspended in $10 \mathrm{~mL}$ of distilled water in a test-tube and stirred with a glass rod to ensure uniform mixing, taking care to avoid formation of lumps. The test-tube was then incubated at $90{ }^{\circ} \mathrm{C}$ for 15 minutes, cooled to room temperature at $25^{\circ} \mathrm{C}$ and then centrifuged for 10 minutes. The supernatant was decanted into an aluminium dish and dried in an oven at $100{ }^{\circ} \mathrm{C}$ for 12 hours. The sediment mass was taken and recorded. WSI and WAI were calculated as below.

$$
\begin{gathered}
\text { WAI }=\frac{\text { Mass of sediment }(\mathrm{g})}{\text { Mass of dry matter }(\mathrm{g})} \\
\text { WSI }=\frac{\text { Mass of dissolved solid in supernatant }(\mathrm{g})}{\text { Mass of the original sample }(\mathrm{g})} \times 100
\end{gathered}
$$




\section{Ml Macrothink}

\subsection{Analysis of Flours}

\subsubsection{Samples and Sample Preparation}

Millet-soybean flour was processed using the optimum extrusion conditions (feed temperature of $60{ }^{\circ} \mathrm{C}$, barrel temperature of $159{ }^{\circ} \mathrm{C}$ and feed moisture content of $25 \%$ ). Pure millet was also processed using similar conditions. The samples were then analyzed for proximate composition, microbial quality, shelf stability and sensory properties.

\subsubsection{Proximate Composition}

Extruded instant millet-soybean flour, extruded pure millet and the raw millet-soybean flour were analysed for proximate composition using AOAC (2005) methods. The moisture content of the flours was determined using an air oven dryer (method No. 930.29), protein content by Kjeldahl procedure (method No.970.22), ash content by hot furnace and crude fat by the soxhlet extraction method.

\subsubsection{Shelf Stability Analysis}

The shelf stability of the extruded millet-soybean flour produced using optimal conditions was monitored for a period of 4 weeks by determining microbial quality (total plate count, yeasts and molds and total coliforms) and free fatty acids on day 0, after 2 weeks and 4 weeks. The samples of the extruded millet-soybean flour were kept packaged in air tight polythene bags and stored at room temperature.

\subsubsection{Total Plate Count}

The total plate count was determined by pour plating selected serial dilutions of the sample in sterile plate count agar (Laboratorios CONDA, Madrid, Spain). The petri dishes were incubated at $37^{\circ} \mathrm{C}$ for 24 hours (ISO, 2003). A negative control plate was included to check for sterility. Colonies were enumerated using a colony counter (Stuart SC6, Staffordshire, UK).

\subsubsection{Yeasts and Molds}

Yeasts and molds were enumerated by surface spreading selected serial dilutions of the sample on sterile pre-poured acidified potato dextrose agar (Laboratorios CONDA, Madrid, Spain). The petri dishes were incubated at $25{ }^{\circ} \mathrm{C}$ for 5 days. A negative control plate was included to check for sterility (ISO, 2008). Colonies were enumerated using a colony counter (Stuart SC6, Staffordshire, UK).

\subsubsection{Total Coliforms}

Total coliforms were determined by pour plating selected serial dilutions of the sample in sterile violet red bile lactose agar (Laboratorios CONDA, Madrid, Spain). The petri dishes were incubated at $37{ }^{\circ} \mathrm{C}$ for 24 hours (ISO, 2009). A negative control plate was included to check for sterility. Colonies were enumerated using a colony counter (Stuart SC6, Staffordshire, UK).

\subsubsection{Determination of Free Fatty Acids}

Determination of percentage free fatty acids was done according to the method of Kirk and Sawyer (1991). Diethylether $(25 \mathrm{~mL})$, alcohol $(25 \mathrm{~mL})$ and 1\% phenolphthalein solution (1 $\mathrm{mL}$ ) were mixed and the mixture neutralized using $0.1 \mathrm{M} \mathrm{NaOH}$ solution. A portion $(2 \mathrm{~g})$ of the sample was dissolved in the mixed neutral solvent and titrated with $0.1 \mathrm{M} \mathrm{NaOH}$, while 


\section{Macrothink}

shaking constantly, until a pink color was formed and persisted for $15 \mathrm{~s}$. The acid value was divided by 1.99 to obtain the oleic acid equivalent which are presented.

\subsection{Sensory Acceptability of the Gruels Prepared Using Optimised Extruded Millet-Soybean} Flour

After optimization, sensory evaluation of the gruels was carried out using an untrained panel. The untrained sensory panel $(n=50)$ comprised of students and staff aged 18-65 years from Makerere University School of Food Technology, Nutrition and Bioengineering. The extruded pure millet, extruded millet-soybean and widely accepted extruded commercial product (made of millet, soybeans, common beans, grain amaranth, rice and carrots) were made into gruel using hot water $(75 \mathrm{~g} / 500 \mathrm{~mL})$ while stirring to avoid formation of lumps, after which $50 \mathrm{~g}$ of sugar was added. The panellists were presented with $50 \mathrm{~mL}$ samples in $200 \mathrm{~mL}$ colorless disposable plastic cups. Panellists scored the samples for appearance, taste, color, flavor, mouth feel, aroma and general acceptability on a 9-point Hedonic scale (Meilgaard et al., 1999).

\subsection{Data Analysis}

Design-expert statistical software was used for optimizing the millet-soybean flour extrusion conditions by application of response surface methodology (RSM) procedures. The statistical significance of the terms in the regression equations and adequacy of the model was examined using ANOVA for each response with $\alpha$-value $(p<.05)$. Desirability function approach (DFA) was used for multiple response optimization. Statistical analysis for proximate analysis, shelf stability and sensory acceptability data was performed using the Statistical Package for Social Science (SPSS) software (version 19). A probability value of difference $\mathrm{p}<.05$ was considered to denote statistical significance.

\section{Results and Discussion}

\subsection{Fitting the Response Surface Models for WAI and WSI}

The "fitness" of the models and their suitability to accurately predict the variation was depicted by coefficients of determination $\left(\mathrm{R}^{2}\right)$, probability values and lack-of-fit F-values (Table 4). Table 4 shows significant model terms for WSI and WAI of extruded millet-soybean flour. The regression models for WAI and WSI were all significant $(p<.05)$. Regarding the lack-of-fit test, both WAI and WSI model results were not significant $(\mathrm{p}>.05)$. Lack of fit measures the inability of the model to represent data in the experimental domain at points which are not included in the regression model. 


\section{Macrothink}

Table 4. Estimated coefficients for the fitted second-order polynomial representing the relationship between the WAI and WSI and process parameters

\begin{tabular}{lll}
\hline Variables & WAI & WSI \\
\hline Constant & 2.24 & 45.90 \\
X1(temperature) & $0.71^{\mathrm{a}}$ & $0.84^{\mathrm{a}}$ \\
$\mathrm{X}_{2 \text { (moisture) }}$ & $0.42^{\mathrm{a}}$ & $-0.59^{\mathrm{a}}$ \\
$\mathrm{X}_{11}$ & $-0.97^{\mathrm{a}}$ & $0.20^{\mathrm{b}}$ \\
$\mathrm{X}_{22}$ & $0.15^{\mathrm{b}}$ & $0.95^{\mathrm{a}}$ \\
$\mathrm{X}_{12}$ & $-0.79^{\mathrm{a}}$ & $3.81^{\mathrm{b}}$ \\
$\mathrm{R}^{2}$ & 0.80 & 0.75 \\
Lack of fit (F value) & $9.08^{\mathrm{b}}$ & $12.8^{\mathrm{b}}$ \\
\hline
\end{tabular}

a Significant at $5 \%$ level ${ }^{\mathrm{b}}$ Not significant WAI: Water absorption index, WSI: Water solubility index.

Statistical analysis indicates that the fit quality of the models in Table 4 was good $\left(\mathrm{R}^{2}\right.$ of 0.8 for WAI and 0.75 for WSI). $\mathrm{R}^{2}$ represents the proportion of variability in the response values explained by the model. The barrel temperature and moisture were found to significantly influence WAI and WSI. Their relationships were represented by a number of predictive models (equation 3 and 4). Hence, it can be concluded that the proposed models (equation 3 and 4) approximate the response surfaces and can be used to predict values for response variables within experimental range. Model reduction was carried out by dropping the insignificant terms based on the p-value $>.05$ in order to improve the model (Equation 3 and 4). 
Table 3. D-optimal design with the observed responses for water absorption index (WAI) and water solubility index (WSI) for instant composite millet soy flour

\begin{tabular}{|c|c|c|c|c|c|}
\hline \multirow[b]{2}{*}{ Standard order } & \multirow[b]{2}{*}{ Run } & \multicolumn{2}{|c|}{ Independent variables } & \multicolumn{2}{|c|}{ Dependent Variables } \\
\hline & & $\begin{array}{l}\text { Temperature } \\
\left({ }^{\circ} \mathrm{C}\right)\end{array}$ & $\begin{array}{l}\text { Moisture } \\
(\%)\end{array}$ & $\begin{array}{l}\text { WAI } \\
(\mathrm{g} / \mathrm{g})\end{array}$ & $\begin{array}{l}\text { WSI } \\
(\%)\end{array}$ \\
\hline 15 & 1 & -1 & +1 & 2.33 & 48.11 \\
\hline 13 & 2 & +1 & +1 & 1.92 & 50.74 \\
\hline 1 & 3 & +1 & -1 & 2.02 & 52.9 \\
\hline 8 & 4 & +1 & -1 & 2.04 & 51.1 \\
\hline 9 & 5 & -1 & 0 & 2.03 & 47.6 \\
\hline 14 & 6 & +1 & -1 & 2.07 & 51.3 \\
\hline 2 & 7 & -1 & 0 & 2.54 & 44.41 \\
\hline 11 & 8 & 0 & -1 & 2.08 & 50.02 \\
\hline 4 & 9 & -1 & -1 & 2.02 & 50.02 \\
\hline 12 & 10 & 0 & 0 & 2.04 & 48.88 \\
\hline 3 & 11 & 0 & -1 & 2.14 & 50.80 \\
\hline 10 & 12 & -1 & -1 & 2.02 & 50.90 \\
\hline 5 & 13 & +1 & +1 & 1.95 & 51.37 \\
\hline 7 & 14 & 0 & -1 & 2.12 & 50.74 \\
\hline 6 & 15 & 0 & 0 & 2.42 & 43.38 \\
\hline
\end{tabular}

WAI-water absorption index WSI-water soluble index ${ }^{a}$ Randomized and ${ }^{b}$ Non-Randomized.

\subsection{Effect of Extrusion Conditions on Water Absorption Index of Instant Millet-Soybean Composite Flour}

WAI is the ability of the starch to absorb and hold water when the starch is dispersed in water and is higher when the degree of starch damage due to gelatinization is high (Rodriguez-Miranda et al., 2011; Filli et al., 2010). Therefore, high WAI value indicates the presence of large starch fragments in the final product. The extrudates exhibited WAI in the range of $1.92 \mathrm{~g} / \mathrm{g}$ and $2.54 \mathrm{~g} / \mathrm{g}$ (Table 3). The relationship between barrel temperature and feed moisture content and WAI was described by a quadratic effect model (Equation 3 ) which was built through regression based on the coefficient data in Table 4 . The $\mathrm{R}^{2}$ of the second order polynomial model was good and explained $80 \%$ of the variability.

Final equation in terms of actual factors:

$$
\text { Water absorption Index }=2.24-0.97 \mathrm{x}_{1}^{2}-0.79 \mathrm{x}_{1} \mathrm{x}_{2}+0.71 \mathrm{x}_{1}+0.42 \mathrm{x}_{2}\left(\mathrm{R}^{2}=0.80\right)
$$

Where $\mathrm{x}_{1}=$ Extrusion temperature, $\mathrm{x}_{2}=$ Feed moisture content 


\section{Macrothink}

The quadratic terms of extrusion temperature $\left(\mathrm{Bx}_{1}^{2}\right)$ and the interaction term for barrel temperature and feed moisture $\left(\mathrm{Bx}_{12}\right)$, linear term for moisture $\left(\mathrm{Bx}_{2}\right)$ and barrel temperature $\left(\mathrm{Bx}_{1}\right)$ were found to be significant $(\mathrm{p}<.05)$ (Table 4). It is also evident from the model that the quadratic term effect of temperature was the most important for WAI in the model compared to the other terms. The quadratic term of temperature and interaction term between moisture and barrel temperature had a significant negative effect on WAI. In a similar way, it is evident from the parabolic shape of the curve illustrated in figure 1A that the quadratic effect of temperature on WAI was negative. The positive linear effect of barrel temperature and feed moisture (equation 3) shows that WAI, temperature and feed moisture content increased in the same direction. Other researchers (Chiu et al., 2013; Kumar et al. 2010; Chakraborty et al., 2011; Sobukola et al., 2013) also reported an increase in WAI associated with an increase in barrel temperature of extruded composite flours. At higher temperature, starch granules are disrupted and more water is bound to the starch molecule resulting in increased WAI. Filli et al. (2010) reported decrease in WAI as extrusion temperature for millet-soybean blend increased.

In the present study, feed moisture had a remarkably significant positive effect on WAI. A number of researchers have investigated the effect of increasing feed moisture level during extrusion, for different formulations of extrudates, and the subsequent raise in WAI (Ding et al., 2005; Singh et al., 2007; Joshi et al., 2014; Semasaka et al., 2010; Chakraborty et al., 2011). High moisture content is associated with low viscosity of starch, which permits extensive internal mixing and uniform heating, leading to enhanced starch gelatinization and higher water absorption (Hagenimana et al., 2006; Suksomboon et al., 2011). Findings of the current study concur with Ding et al. (2005) and Singh et al. (2007) who studied extrudates made from rice and with pea grit but differ from finding by Sobukola et al. (2013) who reported reduction in WAI for extruded yam-based pasta as feed moisture reduced. The difference could be explained by the difference in ingredients used, since the effect of extrusion depends on raw materials composition (Gupta et al., 2008). The model had a non significant lack of fit which suggests a good fit to the model represented by Equation (3). This means that this model is valid and can be used in subsequent prediction and optimisation stages.

\subsection{Effect of Extrusion Conditions on WSI for Instant Millet-Soy Composite Flour}

Water solubility index, which is considered an indicator for starch degradation during extrusion, is related to dextrinization (Yang et al., 2008; Sibel \& Fahrettin, 2008). The extrudates exhibited WSI varying from $43.38 \%$ to $52.9 \%$ (Table 3). The relationship between WSI and extrusion temperature and feed moisture was described by a quadratic effect (Equation 4 ). The $\mathrm{R}^{2}$ of the model was good and explained $75 \%$ of the variability.

Final equation in terms of actual factors

$$
\text { WSI }=45.9+0.95 \mathrm{x}_{2}^{2}+0.83 \mathrm{x}_{1}-0.59 \mathrm{x}_{2}\left(\mathrm{R}^{2}=0.75\right)
$$

Where $\mathrm{x}_{1}=$ Extrusion temperature $\mathrm{x}_{2}=$ Feed moisture

Based on Equation 4, the coefficient of the quadratic effect and linear term of feed moisture and temperature were the only significant terms. The positive quadratic effect of feed moisture is shown by the concave response of WSI in Figure 1 B. Positive linear coefficient of temperature indicates that increase in temperature increases WSI. This observation is 


\section{Macrothink}

consistent with Semasaka et al. (2010) and Ding et al. (2005) who reported an increase in WSI with increase in temperature in extruded corn, millet and, soybean blend and rice-based expanded snack. The higher WSI at the higher extrusion temperature was due to starch dextrinization and depolymerization resulting in higher soluble carbohydrates and greater WSI (Ding et al., 2005; Lei et al., 2005). Similarly, Sobukola et al. (2013) reported increase in WAI with increase in barrel temperature, attributing WAI increase to higher solubility of starch molecules. The negative linear coefficient of feed moisture indicates that increase in feed moisture content progressively decreased the WSI of the millet-soybean composite flour exudate.

The findings of the current study are consistent with other studies (Suksomboon et al., 2011; Ding et al., 2005; Lei et al., 2005; Onyango et al., 2004) that investigated the effect of feed moisture on WSI in rice-based and maize-finger millet extrudates. These results may be explained by the fact that higher feed moisture content reduces viscosity, shearing effect and residence time in the internal surface of the barrel, leading to minimum damage to starch granules and thus decreased WSI of the exudate (Panuwat, 2004). The model had a non significant $(p=.09)$ lack of fit, which suggests a good fit to the model represented by Equation (4). This means that this model is valid and can be used in subsequent prediction and optimisation stages.

\subsection{Optimization of Extrusion Temperature and Moisture of Millet-Soy Instant Flour}

The optimum processing conditions for millet-soybean composite flour was determined by superimposing the contour plots of WAI and WSI in Figure 1A and 1B, respectively. The extrusion temperature of $159{ }^{\circ} \mathrm{C}$ and moisture of $25 \%$ were chosen as optimum conditions that resulted in a product with the highest solubility (0.818) (Table 5).

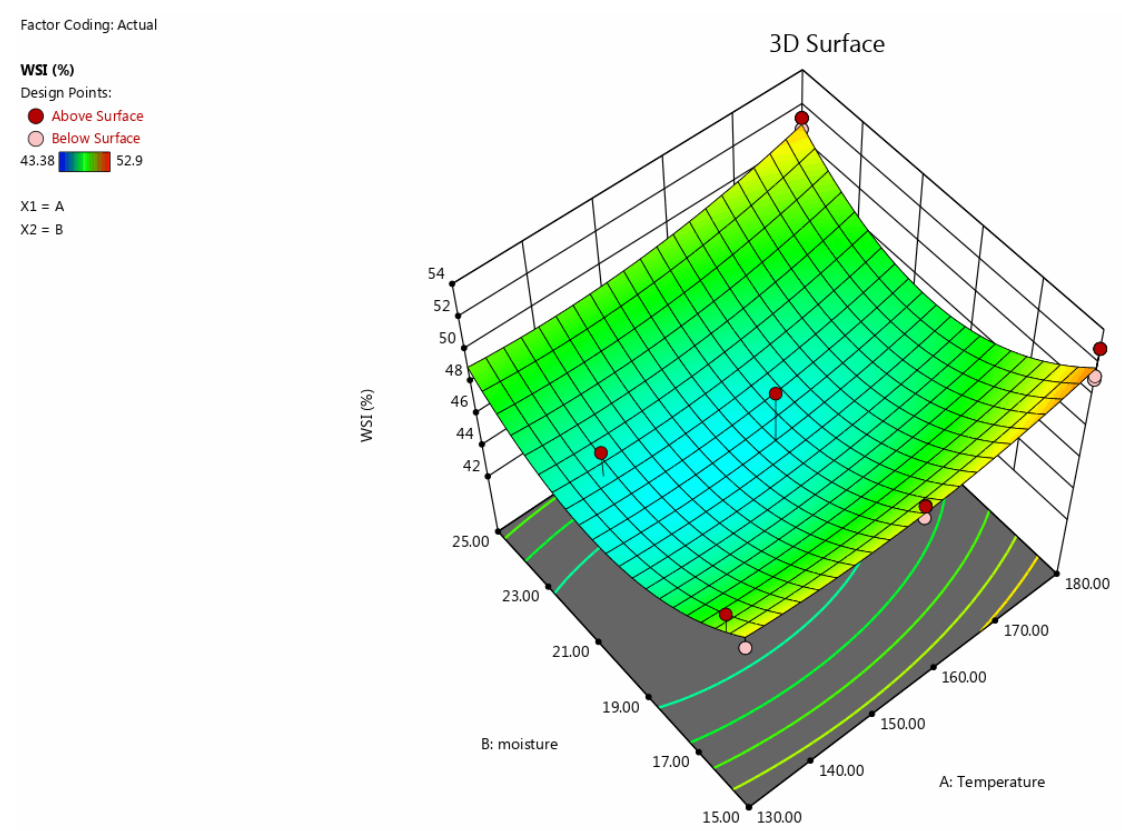

Figure 1A 


\section{Macrothink}
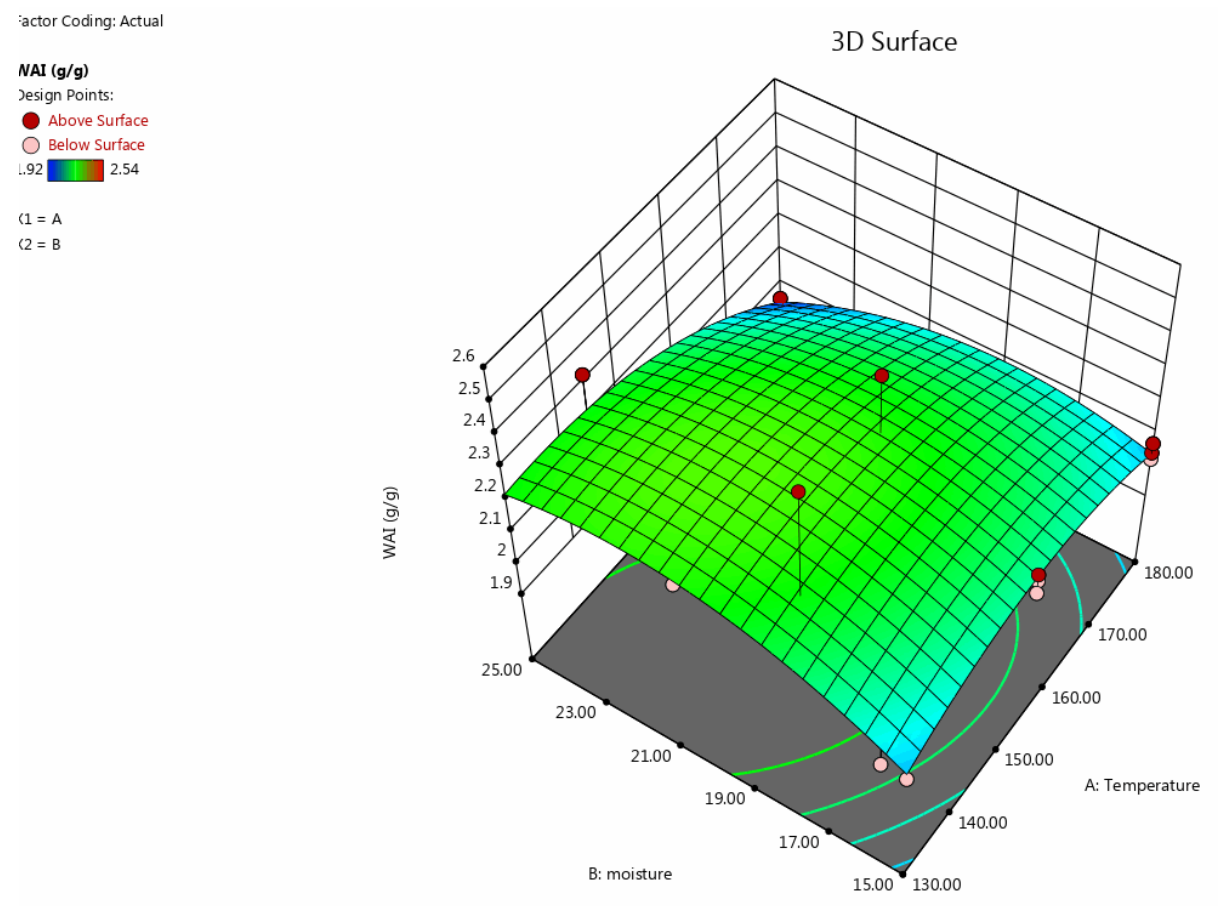

Figure 1B

Figure 1. 3-D Response surface plots showing the effect of barrel temperature and feed moisture on Water Solubility Index, WSI (A) and Water Absorption Index, WAI (B)

\subsubsection{Verification of Models}

Extrusion was then conducted at the optimum conditions (extrusion temperature at $159{ }^{\circ} \mathrm{C}$ and moisture $25 \%$ ) and properties of extrudate compared to predicted values. The predicted WAI and WSI for these conditions was 2.124 and 51.3, respectively (Table 5). The experimental values as shown in Table 6 were found to be in agreement with the predicted range and thus the model is valid for optimising the extrusion process for millet-soybean composite flour. 
Table 5. Optimal extrusion condition showing maximum desirability

\begin{tabular}{llllll}
\hline Number & Temperature $/{ }^{\circ} \mathrm{C}$ & Moisture (\%) & WAI & WSI & Desirability \\
\hline 1 & 159.32 & 25 & 2.124 & 51.3 & $0.818^{*}$ \\
2 & 159.81 & 25 & 2.123 & 51.11 & 0.818 \\
3 & 160.58 & 25 & 2.121 & 50.8 & 0.818 \\
4 & 163.17 & 25 & 2.111 & 49.75 & 0.817 \\
\hline
\end{tabular}

*Selected extrusion condition. WAI is Water Absorption Index $\left(\mathrm{gH}_{2} \mathrm{O} / \mathrm{g}\right)$ and WSI is water soluble index $(\%)$.

Table 6. Comparison of optimum predicted and experimental values for the response variables WAI and WSI

\begin{tabular}{llllll}
\hline Response & Predicted value & SE Mean & 95\% CI (low) & 95\%CI (high) & Observed value \\
\hline WAI $(\mathrm{g} / \mathrm{g})$ & 2.12 & 0.09 & 1.69 & 2.56 & $2.05 \pm 1.11$ \\
WSI $(\%)$ & 51.30 & 7.45 & 22.34 & 59.22 & $45.00 \pm 0.42$ \\
\hline
\end{tabular}

WAI is $\left(\mathrm{gH}_{2} \mathrm{O} / \mathrm{g}\right)$ and WSI is (\%): Observed values are means of triplicate determinations \pm standard deviation.

\subsection{Proximate Composition of the Optimised Instant Millet-Soybean Composite Flour}

Generally, the raw millet-soybean and extruded millet-soybean flour had markedly higher protein and lipid content than extruded pure millet flour (Table 7). The only difference in the solid components between the extruded and raw millet-soy blend was in lipid content, with the extruded blend exhibiting lower content. This difference may be attributed to lipid release as free oil at the die and to complexing of fatty acids with amylose (Singh et al., 2007). Previous studies have shown that extrusion cooking does not significantly affect fibre (Singh et al., 2007; Huber, 2001), protein (Anuonye et al., 2012) or ash (Alonso et al., 2001) content of food. 


\section{Macrothink}

Table 7. Proximate composition of extruded pure millet, extruded millet-soybean flour and raw millet-soybean flour

\begin{tabular}{llll}
\hline Parameter & $\begin{array}{l}\text { Raw millet-soybean } \\
\text { blend }\end{array}$ & $\begin{array}{l}\text { Extruded } \\
\text { millet-soybean blend }\end{array}$ & $\begin{array}{l}\text { Extruded pure } \\
\text { millet }\end{array}$ \\
\hline Ash (\%) & $3.1 \pm 0.12^{\mathrm{a}}$ & $3.0 \pm 0.16^{\mathrm{a}}$ & $2.5 \pm 0.01^{\mathrm{c}}$ \\
Moisture (\%) & $8.9 \pm 0.09^{\mathrm{a}}$ & $4.9 \pm 0.15^{\mathrm{b}}$ & $3.0 \pm 0.08^{\mathrm{c}}$ \\
Lipids (\%) & $6.5 \pm 0.06^{\mathrm{a}}$ & $5.7 \pm 0.14^{\mathrm{b}}$ & $1.8 \pm 0.06^{\mathrm{c}}$ \\
Fibre (\%) & $9.6 \pm 0.78^{\mathrm{a}}$ & $9.7 \pm 0.34^{\mathrm{a}}$ & $9.2 \pm 0.69^{\mathrm{a}}$ \\
Proteins (\%) & $21.9 \pm 0.08^{\mathrm{a}}$ & $21.4 \pm 0.35^{\mathrm{a}}$ & $10.1 \pm 0.05^{\mathrm{b}}$ \\
\hline
\end{tabular}

Values represent means \pm standard deviation of triplicate determination. Values in the same row with the same superscripts $(\mathrm{a}-\mathrm{c})$ are not significantly different $(\mathrm{p}<0.05)$.

According to Luter and Dewey (2003), complementary flours for feeding of children aged 6-23 should contain 6-11 g of protein and $12.7 \mathrm{~g}$ of fat per $100 \mathrm{~g}$. The blended flours therefore contained adequate levels of protein but lower fat than recommended.

3.6 Sensory Acceptability of Extruded Millet-Soybean Blend, Extruded Pure Millet and Commercial Counterpart Extruded Composite Flour

Generally, the mean scores for all the sensory attributes of the products ranged from 6.0 (like slightly) to 8.9 (like very much) (Table 8). Commercial extruded counterpart product had significantly higher overall acceptability scores compared to extruded millet-soybean flour and pure millet.

Aroma, taste, mouth feel and overall acceptability scores for commercial extruded flour gruels were significantly higher than those from extruded pure millet and extruded millet-soybean flours. This may be attributed to the fact that the commercial extruded flour is made from various ingredients including millet, rice, grain amaranth, carrots, beans and soybean thus superior flavor, aroma, taste and mouth feel. Extruded millet-soybean blend was not significantly different from the extruded pure millet in all attributes apart from flavor. 
Table 8. Sensory acceptability of the gruels from the extruded pure millet, extruded millet-soybean and extruded commercial counterpart extruded flour

\begin{tabular}{llll}
\hline & Commercial product & Millet-soybean blend & Pure millet \\
\hline Appearance & $8.9 \pm 1.69^{\mathrm{a}}$ & $6.8 \pm 1.39^{\mathrm{a}}$ & $7.1 \pm 1.50^{\mathrm{a}}$ \\
Colour & $6.9 \pm 1.71^{\mathrm{a}}$ & $6.9 \pm 1.14^{\mathrm{a}}$ & $6.8 \pm 1.62^{\mathrm{a}}$ \\
Flavour & $6.9 \pm 1.6^{\mathrm{a}}$ & $6.7 \pm 1.32^{\mathrm{a}}$ & $6.0 \pm 1.40^{\mathrm{b}}$ \\
Aroma & $7.2 \pm 1.68^{\mathrm{a}}$ & $6.4 \pm 1.52^{\mathrm{b}}$ & $6.1 \pm 1.46^{\mathrm{b}}$ \\
Taste & $7.4 \pm 1.52^{\mathrm{a}}$ & $6.7 \pm 1.51^{\mathrm{b}}$ & $6.2 \pm 1.35^{\mathrm{b}}$ \\
Mouth feel & $7.6 \pm 1.52^{\mathrm{a}}$ & $6.6 \pm 1.70^{\mathrm{b}}$ & $6.4 \pm 1.69^{\mathrm{b}}$ \\
Overall acceptability & $7.6 \pm 1.20^{\mathrm{a}}$ & $6.6 \pm 1.49^{\mathrm{b}}$ & $6.3 \pm 1.60^{\mathrm{b}}$ \\
\hline
\end{tabular}

Values are means \pm standard deviation $(\mathrm{n}=50)$. Mean values in the same row with different superscripts $(a-b)$ are significantly different $(p<.05)$. The hedonic scale used was: $9=$ like extremely, $8=$ like very much, $7=$ like moderately, $6=$ like slightly, $5=$ neither like nor dislike, 4= dislike slightly, $3=$ dislike moderately, $2=$ dislike very much, $1=$ dislike extremely.

Sensory scores are an indication of the potential of a product to compete on the market, once well packaged, priced and promoted. The optimised extruded millet-soybean blend recorded overall sensory acceptability score $>6$ (like slightly), which was similar to the score for pure millet, a widely consumed product. This indicates that the optimised extruded millet-soybean blend can successfully compete on the commercial market.

\subsection{Shelf Stability of the Optimized Extruded Millet-Soybean Flour}

Yeasts, molds and total coliforms were not detected in extruded millet-soybean flour (Table 9).

Table 9. Microbial counts and free fatty acids content for extruded millet-soybean flour

\begin{tabular}{lllll}
\hline \multirow{2}{*}{$\begin{array}{l}\text { Time } \\
\text { (days) }\end{array}$} & Free fatty & \multicolumn{2}{l}{ Microbial Counts $(\log$ cfu/g) } & \\
\hline 0 & acids $(\%)$ & Total plate count & Yeasts and molds & Total coliforms \\
14 & $0.21 \pm 0.00^{\mathrm{a}}$ & $1.35 \pm 0.60^{\mathrm{a}}$ & $\mathrm{ND}$ & $\mathrm{ND}$ \\
28 & $0.26 \pm 0.04^{\mathrm{a}}$ & $2.32 \pm 0.79^{\mathrm{b}}$ & $\mathrm{ND}$ & $\mathrm{ND}$ \\
\hline
\end{tabular}

Values are means \pm standard deviation of triplicate determination. ND; Not detected.

There was no significant change in \% fatty acids content of the optimized millet-soybean composite flour over a storage period of 28 days. This is probably due to denaturation of hydrolytic enzymes during the extrusion process (Singh et al., 2007). The free fatty acids ranged between $0.21 \%$ and $0.3 \%$ throughout the storage period. The TPC results were in the 


\section{MInstitute ${ }^{\text {Macrothink }}$}

range $1.3-2.9 \log \mathrm{cfu} / \mathrm{g}$ at the end of storage period of a month. Coliforms and yeast and molds were not detected throughout the storage period of one month. The results for free fatty acids and microbial load were considerably lower that recommended upper limits (UNBS, 2012). This indicates that the extruded millet soy flour is stable on the shelf within a period of a month.

\section{Conclusion}

D- Optimal successfully disclosed the effect of independent variables (feed moisture content and barrel temperature) on the response variables (WAI and WSI) of extrudates developed from millet-soy blend composite flour. The developed models were found to be statistically valid and adequately predicted extrudate characteristics for different processing conditions. High barrel temperature was associated with high water absorption of extruded millet-soybean composite flour while high feed moisture was associated with high WAI and low WSI. The optimized processing conditions were found to be feed moisture content of $25 \%$ and barrel temperature $\left(159{ }^{\circ} \mathrm{C}\right)$ and these resulted in extrudate with WAI of $2.124 \mathrm{~g}$ $\mathrm{H}_{2} \mathrm{O} / \mathrm{g}$ and WSI of $51.3 \%$. These processing combinations can be recommended in production of highly soluble instant millet-soybean flour. The shelf stability and sensory evaluation results showed that the optimized product is safe and acceptable. Study of the effect of the optimized extrusion conditions on nutrient bioavailability is recommended.

\section{Acknowledgements}

This study was funded by the government of Uganda, through the Presidential support to the Makerere University Food Technology and Business Incubation Centre.

\section{References}

Ali, M. A., El Tinay, A. H., Mohamed Ahmed, I. A., \& Babiker, E. E. (2009). Supplementation of pearl millet with soybean: changes in protein digestibility, amino acid composition and sensory quality during processing. Electronic Journal of Environmental, Agricultural \& Food Chemistry, 8(12).

Alonso, R., Rubio, L. A., Muzquiz, M., \& Marzo, F. (2001). The effect of extrusion cooking on mineral bioavailability in pea and kidney bean seed meals. Animal Feed Science and Technology, 94(1-2), 1-13. https://doi.org/10.1016/S0377-8401(01)00302-9

Anton, A. A., Fulcher, R. G., \& Arntfield, S. D. (2009). Physical and nutritional impact of fortification of corn starch-based extruded snacks with common bean (Phaseolus vulgaris L.) flour: Effects of bean addition and extrusion cooking. Food Chemistry, 113(4), 989-996. https://doi.org/10.1016/j.foodchem.2008.08.050

Anuonye, J. C. (2012). Some functional properties of extruded acha/soybean blends using response surface analysis. African Journal of Food Science, 6(10), 269-279. https://doi.org/10.5897/AJFS12.001

AOAC (2005). Official Methods of Analysis of the Association of Analytical Chemists. Official Method 923.03. 18th ed.; Association of Official Analytical Chemists: Gaithersburg, MD, USA.

Balasubramanian, S., Singh, K. K., Patil, R. T., \& Onkar, K. K. (2012). Quality evaluation of millet-soy blended extrudates formulated through linear programming. Journal of Food Science and Technology, 49(4), 450-458. https://doi.org/10.1007/s13197-011-0297-0 
Barbeau, W. E., \& Hilu, K. W. (1993). Protein, calcium, iron, and amino acid content of selected wild and domesticated cultivars of finger millet. Plant Foods for Human Nutrition, 43(2), 97-104. https://doi.org/10.1007/BF01087914

Boonyasirikool, P., \& Charunuch, C. (2000). Development of nutritious soy fortified snack by extrusion cooking. Kasetsart J (Natural Science), 34, 355-365.

Chakraborty, S.K., Singh, D.S., Kumbhar, B.K. \& Chakraborty, S. (2011). Millet-legume blended extrudates characteristics and process optimization using RSM. Food and Bioproducts Processing, 89, 492-499. https://doi.org/10.1016/j.fbp.2010.10.003

Chiu, H. W., Peng, J. C., Tsai, S. J., Tsay, J. R., \& Lui, W. B. (2013). Process optimization by response surface methodology and characteristics investigation of corn extrudate fortified with yam (Dioscorea alata L.). Food and Bioprocess Technology, 6(6), 1494-1504. https://doi.org/10.1007/s11947-012-0894-6

Diaz, J. M. R., Kirjoranta, S., Tenitz, S., Penttilä, P. A., Serimaa, R., Lampi, A., \& Jouppila, K. (2013). Use of amaranth, quinoa and kañiwa in extruded corn-based snacks. Journal of Cereal Science, 58, 59-67. https://doi.org/10.1016/j.jcs.2013.04.003

Ding, Q. B., Ainsworth, P., Tucker, G., \& Marson, H. (2005). The effect of extrusion conditions on the physicochemical properties and sensory characteristics of rice-based expanded snacks. Journal of Food Engineering, 66(3), 283-289. https://doi.org/10.1016/j.jfoodeng.2004.03.019 Derringer, G. \& Suich, R. (1980). Simultaneous optimization of several response variables. Journal of Quality Technology, 12(4), 214-219. https://doi.org/10.1080/00224065.1980. 11980968

Dykes, L., \& Rooney, L. W. (2006). Sorghum and millet phenols and antioxidants. Journal of Cereal Science, 44(3), 236-251. https://doi.org/10.1016/j.jcs.2006.06.007

ElMaki, H. B., AbdelRahaman, S. M., Idris, W. H., Hassan, A. B., Babiker, E. E., \& El Tinay, A. H. (2007). Content of antinutritional factors and HCl-extractability of minerals from white bean (Phaseolus vulgaris) cultivars: Influence of soaking and/or cooking. Food Chemistry, 100(1), 362-368. https://doi.org/10.1016/j.foodchem.2005.09.060

Filli, K. B., Nkama, I., Abubakar, U. M., \& Jideani, V. A. (2010). Influence of extrusion variables on some functional properties of extruded millet-soybean for the manufacture of fura: A Nigerian traditional food. African Journal of Food Science, 4(6), 342-352.

Gupta, M., Bawa, A. S., \& Semwal, A. D. (2008). Effect of Barley Flour on Development of Rice-Based Extruded Snacks. Cereal chemistry, 85(2), 115-122. https://doi.org/10.1094/ CCHEM-85-2-0115

Hagenimana, A., Ding, X., \& Fang, T. (2006). Evaluation of rice flour modified by extrusion cooking. Journal of Cereal Science, 43(1), 38-46. https://doi.org/10.1016/j.jcs.2005.09.003

Huber, G. (2001). Snack foods from cooking extruders. Snack Foods Processing, 315-367. https://doi.org/10.1201/9781420012545.ch12

ISO (2009). Microbiology of food and animal feeding stuffs - Horizontal method for the enumeration of yeasts and moulds - Part 2: Colony count technique in products with water activity less than or equal to 0.95 . Czech Office for Standards, Meteorology and Testing, ISO 21527-2:2009. 


\section{Macrothink}

Journal of Food Studies

ISSN 2166-1073

2020, Vol. 9, No. 1

ISO (2008). Microbiology of food and animal feeding stuffs - Horizontal methods for the detection and enumeration of Enterobacteriaceae Croatian Standards Institute. Zagreb: ISO 21528-2: 2008

ISO (2003). Horizontal method for the enumeration of microorganisms-Colony-count technique at 30 degrees. Geneva: ISO 4833:2003

Joshi, S. M., Bera, M. B., \& Panesar, P. S. (2014). Extrusion cooking of maize/spirulina mixture: factors affecting expanded product characteristics and sensory quality. Journal of Food Processing and Preservation, 38(2), 655-664. https://doi.org/10.1111/jfpp.12015

Kirk, R. S., \& Sawyer, R. (1991). Pearson's composition and analysis of foods (9th ed.) (pp. 640, 643). UK: Longman Scientific and Technical.

Kumar, N., Sarkar, B. C., \& Sharma, H. K. (2010). Development and characterization of extruded product of carrot pomace, rice flour and pulse powder. African Journal of Food Science, 4(11), 703-717.

Lei, H., Fulcher, R. G., Ruan, R., \& van Lengerich, B. (2005). SME-Arrhenius model for WSI of rice flour in a twin-screw extruder. Cereal Chemistry, 82(5), 574-581. https://doi.org/10.1094/CC-82-0582

Luter, C.K., \& Dewey, K.G. (2003). Proposed nutrient composition for fortified complementary foods. The Journal of Nutrition, 133(9), 3011S-3020S. https://doi.org/10. 1093/jn/133.9.3011S

Mbithi-Mwikya, S., Van Camp, J., Mamiro, P. R., Ooghe, W., Kolsteren, P., \& Huyghebaert, A. (2002). Evaluation of the nutritional characteristics of a finger millet based complementary food. Journal of Agricultural and Food Chemistry, 50(10), 3030-3036. https://doi.org/10. $1021 / \mathrm{jf0} 11008 \mathrm{a}$

Meilgaard, M. C., Carr, B. T., \& Civille, G. V. (1999). Sensory Evaluation Techniques. CRC press. https://doi.org/10.1201/9781439832271

Myers, R.H., Montgomery, D.C. \& Anderson-Cook, C.M. 2009. Response Surface Methodology: Process and product optimization using designed experiments. John Wiley \& Sons, Hoboken, NJ.

Navam, S. H., Tajudini, A. L., Srinivas, J. R., Sivarooban, T., \& Kristofor, R. B. (2014). Physio-Chemical and Sensory Properties of Protein-Fortified Extruded Breakfast Cereal/Snack Formulated to Combat Protein Malnutrition in Developing Countries. Journal of Food Processing \& Technology, 5(8), 1.

Onyango, C., Noetzold, H., Bley, T., \& Henle, T. (2004). Proximate composition and digestibility of fermented and extruded uji from maize-finger millet blend. LWT-Food Science and Technology, 37(8), 827-832. https://doi.org/10.1016/j.lwt.2004.03.008

Panuwat, S. (2004). Modification of Low Amylase Rice Flour and Starch by Extrusion Cooking and Drum Drying. Doctoral Thesis, Bangkok, Thailand: Asian Institute of Technology

Rodríguez-Miranda, J., Ruis-López, I., Herman-Lara, E. Martínez-Sánchez, C.E. \& Vivar-Vera, M.A. 2011. Development of extruded snacks using taro (Colocasia esculenta) and nixtamalized maize (Zea mays) flour blends. LWT Food Science and Technology, 44: 
673-680. https://doi.org/10.1016/j.lwt.2010.06.036

Semasaka, C., Kong, X., \& Hua, Y. (2010). Optimization of extrusion on blend flour composed of corn, millet and soybean. Pakistan Journal of Nutrition, 9(3), 291-297. https://doi.org/10.3923/pjn.2010.291.297

Seth, D., \& Rajamanickam, G. (2012). Development of extruded snacks using soy, sorghum, millet and rice blend-A response surface methodology approach. International Journal of Food Science \& Technology, 47(7), 1526-1531. https://doi.org/10.1111/j.1365-2621. 2012.03001.x

Sibel, Y. \& Fahrettin, G. (2008). Response Surface Methodology for Evaluation of Physical and Functional Properties of Extruded Snack Food Developed from Food-by-products. Journal of Food Engineering, 86(1), 122-132. https://doi.org/10.1016/j.jfoodeng.2007.09.018

Singh, S., Gamlath, S., \& Wakeling, L. (2007). Nutritional aspects of food extrusion: a review. International Journal of Food Science \& Technology, 42(8), 916-929. https://doi.org/10.1111/j.1365-2621.2006.01309.x

Sobukola, O. P., Babajide, J. M., \& Ogunsade, O. (2013). Effect of brewers spent grain addition and extrusion parameters on some properties of extruded yam starch-based pasta. Journal of Food Processing and Preservation, 37(5), 734-743. https://doi.org/10.1111/j.1745-4549. 2012.00711.x

Suksomboon, A., Limroongreungrat, K., Sangnark, A., Thititumjariya, K., \& Noomhorm, A. (2011). Effect of extrusion conditions on the physicochemical properties of a snack made from purple rice (Hom Nil) and soybean flour blend. International Journal of Food Science \& Technology, 46(1), 201-208. https://doi.org/10.1111/j.1365-2621.2010.02471.x

Sundarrajan, L. (2014). Effect of extrusion cooking on the nutritional properties of amaranth, quinoa, kañiwa and lupine (Doctoral dissertation, Helsingfors university).

UNBS (2012). Uganda National Bureau of Standards US EAS 782:2012. Composite Flour Specifications.

Vargas-Solorzano, J. W., PilerCarvalho, C. W., Takeiti, Y., Ascheri, J. L. R., \& Queiroz, V. V. A. (2014). Physicochemical properties of expanded extrudates from colored sorghum genotypes. Food Research International, 55, 37-44. https://doi.org/10.1016/j.foodres.2013. 10.023

Yang, S. H., Peng, J., Lui, W. B., \& Lin, J. (2008). Effects of adlay species and rice flour ratio on the physicochemical properties and texture characteristic of adlay-based extrudates. Journal of Food Engineering, 84(3), 489-494. https://doi.org/10.1016/j.jfoodeng.2007.06.010

\section{Copyright Disclaimer}

Copyright for this article is retained by the author(s), with first publication rights granted to the journal.

This is an open-access article distributed under the terms and conditions of the Creative Commons Attribution license (http://creativecommons.org/licenses/by/4.0/). 